\title{
Induction of liver monooxygenases by annatto and bixin in female rats
}

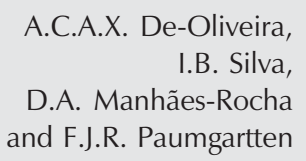

D.A. Manhães-Rocha and F.J.R. Paumgartten

Laboratório de Toxicologia Ambiental, Escola Nacional de Saúde Pública, Fundação Oswaldo Cruz, Rio de Janeiro, RJ, Brasil

\author{
Correspondence \\ F.J.R. Paumgartten \\ Laboratório de Toxicologia Ambiental \\ Escola Nacional de Saúde Pública \\ FIOCRUZ \\ Av. Brasil, 4365 \\ 21045-900 Rio de Janeiro, RJ \\ Brasil \\ Fax: +55-21-2260-1069 \\ E-mail: paum@ensp.fiocruz.br \\ Research supported by \\ PAPES-FIOCRUZ. F.J.R. Paumgartten, \\ I.B. Silva (PIBIC, FIOCRUZ) and \\ D.A. Manhães-Rocha (IC, CNPq) \\ are recipients of fellowships \\ from CNPq.
}

Received April 5, 2002

Accepted October 7, 2002

\begin{abstract}
Annatto or urucum is an orange-yellow dye obtained from Bixa orellana seeds. It has been used as a natural dye in a variety of food products, drugs and cosmetics, and also in Brazilian cuisine as a condiment ('colorau'). Bixin, a carotenoid devoid of provitamin A activity, is the main pigment found in annatto. Some carotenoids (canthaxanthin, astaxanthin and B-Apo-8'-carotenal) are known to be potent inducers of CYP1A1, a property not shared by others (Bcarotene, lycopene and lutein). Little is known, however, about the CYP1A1-inducing properties of bixin and annatto. The present study was performed to determine the effects of an annatto extract $(28 \%$ bixin) and bixin (95\% pure) on rat liver monooxygenases. Adult female Wistar rats were treated by gavage with daily doses of annatto $(250 \mathrm{mg} / \mathrm{kg}$ body weight, which contains approximately $70 \mathrm{mg}$ bixin/ $\mathrm{kg}$ body weight), bixin ( $250 \mathrm{mg} / \mathrm{kg}$ body weight) or the vehicle only (corn oil, $3.75 \mathrm{~g} / \mathrm{kg}$ body weight) for 5 consecutive days, or were not treated (untreated control). The activities of aniline-4-hydroxylase (A4H), ethoxycoumarin- $O$-deethylase (ECOD), ethoxy-(EROD), methoxy- (MROD), pentoxy- (PROD) and benzyloxy- (BROD) resorufin$O$-dealkylases were measured in liver microsomes. Annatto $(250 \mathrm{mg} /$ $\mathrm{kg}$ containing $70 \mathrm{mg}$ bixin $/ \mathrm{kg}$ ) induced EROD (3.8x), MROD (4.2x), BROD (3.3x) and PROD (2.4x). Bixin $(250 \mathrm{mg} / \mathrm{kg}$ ) was a weaker inducer of EROD (2.7x), MROD (2.3x) and BROD (1.9x) and did not alter PROD, A4H or ECOD activities. These results suggest that constituents of the extract other than bixin play an important role in the induction of CYP1A and CYP2B observed with annatto food colorings.
\end{abstract}

Annatto is an orange-yellow dye obtained from the pericarp of seeds from Bixa orellana L. (Bixaceae), a tree native to Central and South America tropical forests $(1,2)$. In Brazil annatto is known as 'urucum' or 'urucu', a word from the Tupi-Guarani language, and in Spanish-speaking America as 'achiote' from the Aztec 'achiotl' (1). The use of annatto by the New World man dates back to ancient times. The indigenous Amazon people have used urucum for body painting for centuries and it is believed that the original Aztec chocolate beverage contained annatto seeds in addition to cocoa. Moreover, seeds and leaves of the annatto tree were used by the Aztecs to prepare remedies for a variety of illnesses such as tonsillitis, asthma, pleurisy, rectal disorders, headache, jaundice, sunstroke, and burns.

Bixin (cis-bixin, CAS 6983-79-5) is the main oil-soluble pigment of $B$. orellana seeds. It is a carotenoid devoid of provitamin $\mathrm{A}$ 
Figure 1. Structures of bixin and other carotenoids which are either non-inducers (lutein, ß-carotene and lycopene) or potent inducers (ß-Apo-8'-carotenal, astaxanthin and canthaxanthin) of CYP1A $1 / 2$ isoforms in the rat liver. activity with two carboxylic groups, one of which is a methyl ester (Figure 1). Hydrolysis of this methyl ester group yields the corresponding dicarboxylic acid, norbixin, which is an annatto pigment soluble in aqueous alkaline solutions. Annatto extracts, as well as their major carotenoid constituents bixin and norbixin, have been widely employed as color additives in food, drugs and cosmetics $(3,4)$. As a food coloring, annatto has been added to butter, cheese, sausages, margarine, ice-cream, cereals and to a variety of other products $(3,4)$. In Northern and Northeastern Brazil, an annatto extract (known as 'colorau' or 'colorífico') is also extensively used as a food condiment.

Carotenoids such as canthaxanthin, astaxanthin and $\beta$-Apo- 8 '-carotenal but not $\beta$ carotene or lycopene, have been reported to be potent inducers of CYP1A1 isoenzymes in rats (5-8) and mice (9). The effects of bixin on xenobiotic metabolizing enzymes, however, have been much less studied. Jewell and O'Brien (8) found that bixin $(300 \mathrm{mg} / \mathrm{kg}$ diet for 16 days) increased ethoxy- (EROD; a marker for CYP1A1), methoxy- (MROD; CYP1A2) and, to a lesser extent, pentoxyresorufin- $O$-dealkylases (PROD; CYP2B1) in the rat liver. To our knowledge, no other report has been published on the effects of bixin and annatto on cytochrome P450 enzymes. The present study was undertaken to investigate the effects of bixin as well as those of an annatto food coloring on the activities of liver monooxygenases in the rat.

Virgin female Wistar rats, approximately 100 days old and weighing 220-260 g, from the CECAL-FIOCRUZ breeding stock were used. The rats were housed four per cage in standard plastic cages with stainless steel cover lids and wood shavings as bedding. The animals were given free access to a rodent pelleted diet (Nuvital ${ }^{\circledR}$, Nuvilab, Curitiba, PR, Brazil) and tap water and were kept under conditions of constant temperature $\left(22 \pm 1^{\circ} \mathrm{C}\right)$, humidity (approximately $70 \%$ ) and photoperiod (12-h light and 12-h dark, lights on 8:00 am). The research protocol was approved by the Ethics Committee on the Use of Animals of Oswaldo Cruz Foundation (CEUA-FIOCRUZ). Annatto (containing 28\% bixin, determined spectrophotometrically) was supplied by Baculerê Agro Industrial Ltda., Olimpia, SP, Brazil, and bixin (purity 95\%) was from Helianthus S.A., Lima, Peru.

The rats were treated by gastric gavage with daily doses of annatto $(250 \mathrm{mg} \mathrm{kg}$ body weight $^{-1}$ day $^{-1}$ containing $70 \mathrm{mg}$ bixin $/ \mathrm{kg}$ ), bixin (250 $\mathrm{mg} \mathrm{kg}$ body weight $^{-1}$ day $^{-1}$ ), or the

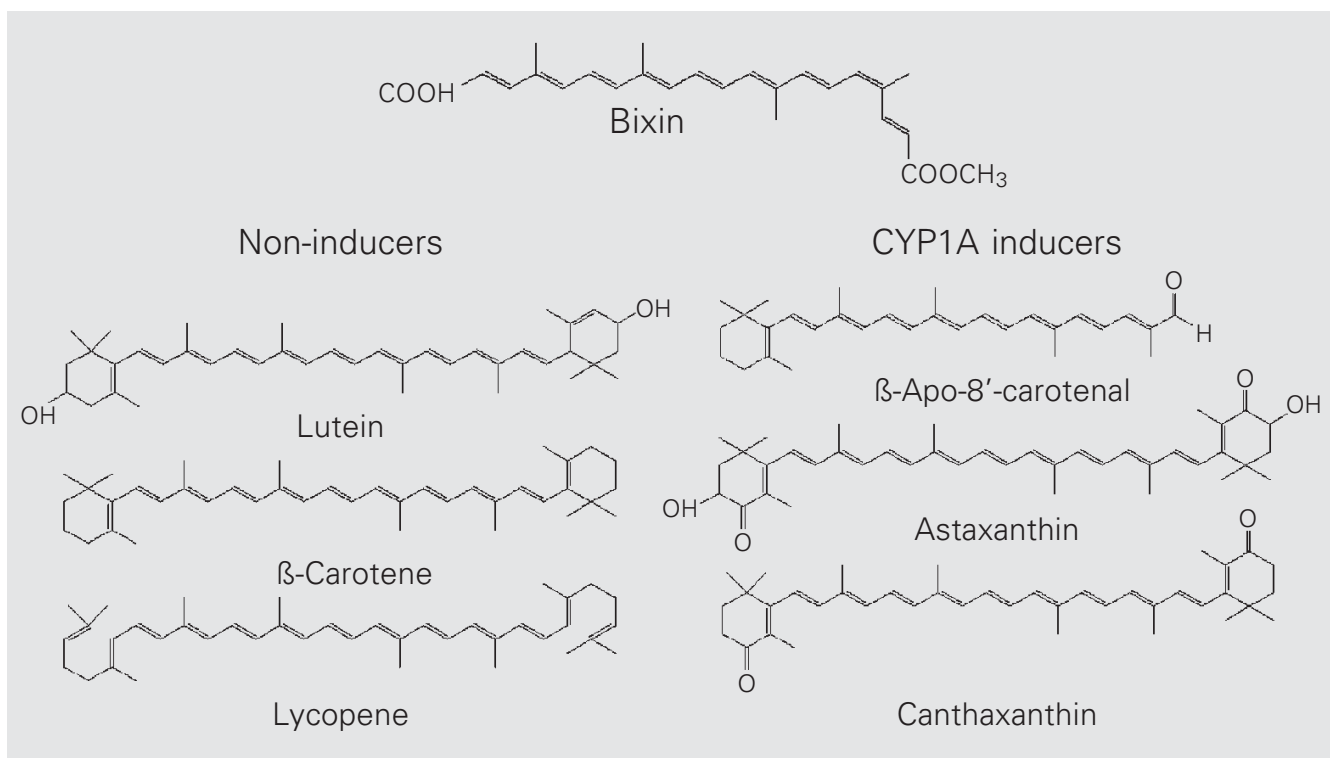


vehicle only (corn oil, $3.75 \mathrm{~g} \mathrm{~kg}$ body weight ${ }^{-1}$ day $^{-1}$ ) for 5 consecutive days. One untreated control group was also run in parallel.

All food was withdrawn after the last dose and the animals were killed by cervical dislocation $16 \mathrm{~h}$ later. After killing, livers were immediately removed, freed from fat and extra tissue and weighed. Liver tissue was homogenized with ice-cold $250 \mathrm{mM}$ sucrose in a glass Potter Elvejhem homogenizer with a Teflon pestle. The homogenate was centrifuged at $9,000 \mathrm{~g}$ for $30 \mathrm{~min}$ and the supernatant obtained was ultracentrifuged at $100,000 \mathrm{~g}$ for $60 \mathrm{~min}$. The pellet was resuspended in $100 \mathrm{mM}$ Tris-HCl buffer, $\mathrm{pH}$ 7.4, and ultracentrifuged again at $100,000 \mathrm{~g}$ for $60 \mathrm{~min}$. The final pellet (microsomal fraction) was then suspended in an ice-cold solution consisting of $0.1 \mathrm{mM}$ EDTA, $20 \%$ glycerol potassium phosphate buffer $(100 \mathrm{mM}$, $\mathrm{pH}$ 7.4) and stored in liquid nitrogen until further use. Protein concentration in the microsomal fraction was quantified by the method of Bradford (10).

Alcoxyresorufin- $O$-dealkylase activities were determined spectrofluorometrically as described by Burke et al. (11) except that an NADPH regenerating system was used (12). 7-Ethoxycoumarin- $O$-deethylase (ECOD) activity was determined as reported by Greenlee and Poland (13) with some minor modifications. Aniline-4-hydroxylase (A4H) was determined spectrophotometrically as described in detail by Gibson and Skett (14). Substrates (pentoxyresorufin, ethoxyresorufin, methoxyresorufin and benzyloxyresorufin, aniline and 7-ethoxycoumarin), reaction products (resorufin, 4-aminophenol and umbelliferone), glucose-6-phosphate, NADP and glucose-6-phosphate dehydrogenase were all from Sigma (St. Louis, MO, USA).

Neither annatto (28\% bixin) nor bixin (95\% pure) given orally at a dose as high as $250 \mathrm{mg} \mathrm{kg}$ body weight $^{-1}$ day $^{-1}$ for 5 consecutive days was overtly toxic to the rats. It should be pointed out that, in a preliminary dose range-finding experiment, $250 \mathrm{mg} / \mathrm{kg}$ body weight was half the highest dose of this powdered annatto extract that was feasible to give by gavage to rats.

As shown in Table 1 , annatto $(250 \mathrm{mg} / \mathrm{kg}$

\begin{tabular}{|c|c|c|c|c|c|c|c|}
\hline \multirow[t]{2}{*}{ Treatment } & \multirow[t]{2}{*}{$N$} & \multirow{2}{*}{ 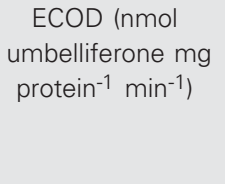 } & \multicolumn{4}{|c|}{$\begin{array}{l}\text { X-ROD activity (pmol resorufin mg } \\
\text { protein }{ }^{-1} \mathrm{~min}^{-1} \text { ) }\end{array}$} & \multirow{2}{*}{$\begin{array}{c}\mathrm{A} 4 \mathrm{H}(\mathrm{nmol} \\
\text { aminophenol mg } \\
\text { protein }^{-1} \mathrm{~min}^{-1} \text { ) }\end{array}$} \\
\hline & & & EROD & MROD & PROD & BROD & \\
\hline $\begin{array}{l}\text { Annatto ( } 28 \% \text { bixin) } \\
\text { Induction factor }\end{array}$ & 5 & - & $\begin{array}{c}195 \pm 129^{a}, \mathrm{~b} \\
3.8\end{array}$ & $\begin{array}{c}195 \pm 90^{\mathrm{a}, \mathrm{b}} \\
4.2\end{array}$ & $\begin{array}{l}19 \pm 10^{\mathrm{a}, \mathrm{b}} \\
2.4\end{array}$ & $\begin{array}{l}30 \pm 18^{a, b} \\
3.3\end{array}$ & - \\
\hline $\begin{array}{l}\text { Bixin (95\% pure) } \\
\text { Induction factor }\end{array}$ & 10 & $\begin{array}{c}1.42 \pm 0.49 \\
1.0\end{array}$ & $\begin{array}{c}138 \pm 66^{a, b} \\
2.7\end{array}$ & $\begin{array}{c}105 \pm 56^{a, b} \\
2.3\end{array}$ & $\begin{array}{c}11 \pm 4 \\
1.4\end{array}$ & $\begin{array}{c}17 \pm 8^{a, b} \\
1.9\end{array}$ & $\begin{array}{c}0.09 \pm 0.02 \\
1.0\end{array}$ \\
\hline Vehicle control group & 12 & $1.36 \pm 0.49$ & $51 \pm 20$ & $46 \pm 16$ & $8 \pm 4$ & $9 \pm 4$ & $0.09 \pm 0.018$ \\
\hline Untreated control group & 8 & $1.31 \pm 0.53$ & $64 \pm 20$ & $46 \pm 20$ & $8 \pm 4$ & $8 \pm 3$ & $0.08 \pm 0.02$ \\
\hline
\end{tabular}


body weight containing $70 \mathrm{mg}$ bixin/ $\mathrm{kg}$ body weight) caused an increase in the activities of EROD (3.8x), MROD (4.2x), benzyloxyresorufin- $O$-dealkylases (BROD) (3.3x) and PROD (2.4x), as compared to the activities found for the vehicle control group. Since in rat liver microsomes EROD and MROD are reactions predominantly catalyzed by CYP1A1 and 1A2, and PROD as well as BROD are catalyzed by isoenzymes belonging to the 2B subfamily (15), the foregoing findings suggest that annatto $(28 \%$ bixin) induced CYP1A1/2 and, to a lesser extent, CYP2B. A slight enhancement of EROD (2.7x), MROD (2.3x) and BROD (1.9x) was also noted among rats treated with $95 \%$ pure bixin (250 mg/kg body weight) (Table 1). The administration of bixin, however, did not change the activities of PROD, ECOD or A4H (Table 1). In rat liver microsomes, the $O$-deethylation of ethoxycoumarin seems to be catalyzed by several CYP450 isoforms including those belonging to subfamilies $1 \mathrm{~A}$, 2A, 2B, 2C, 2E and 3A (16,17). Since EROD is more specific for CYP1A1 than ECOD, the weak inducing effect noted in bixintreated rats was revealed by deethylation reaction of the former but not of the latter. The hydroxylation of aniline at carbon 4 , on the other hand, is predominantly catalyzed by CYP2E1 $(16,18)$.

Our results show that bixin, under the conditions of this study, did not alter CYP2E1 causing only a slight increase in the activities of CYP1A1/2 and 2B. It is noteworthy that the induction of CYP1A and 2B in annattotreated rats was stronger than that found in rats treated with $95 \%$ pure bixin. Since the dose of bixin administered to the former group ( $70 \mathrm{mg} / \mathrm{kg}$ body weight) was approximately three times lower than that given to the latter group ( $250 \mathrm{mg} / \mathrm{kg}$ body weight), these results suggest that constituents of the annatto extract other than bixin were at least partially responsible for the induction of CYP1A1/2 and 2B. A weak inducing effect of bixin, however, cannot be ruled out.
However, it seems unlikely that any liver monooxygenase induction occurs when annatto and bixin are used as food colorings. The daily doses of annatto $(70 \mathrm{mg}$ bixin $\mathrm{kg}$ body weight ${ }^{-1}$ day $^{-1}$ ) and bixin $(250 \mathrm{mg} \mathrm{kg}$ body weight ${ }^{-1}$ day $^{-1}$ ) that caused only a weak enzyme induction in the present study were 1077 and 3846 times, respectively, the current acceptable daily intake established for annatto/bixin $(0.065 \mathrm{mg}$ bixin $\mathrm{kg}$ body weight $^{-1}$ day $^{-1}$ ) (3). Thus, it seems unlikely that any enzyme induction or change in drug metabolism may occur at daily doses resulting from the current use of annatto/bixin as food colorings.

Our results with regard to bixin are, to a certain extent, at variance with those reported by Jewell and O'Brien (8). These investigators found that EROD (CYP1A1) and MROD (CYP1A2) activities were markedly increased in rats fed a bixin-enriched $\operatorname{diet}(300 \mathrm{mg} / \mathrm{kg}$ diet) for 16 days (8). Differences between the two studies with regard to the effects of bixin on EROD, MROD and PROD could have been due to differences in the method of administration (gavage versus diet), gender (female versus male rats), and/ or in the duration of exposure (5 versus 16 days). The daily dose of bixin in the present study, however, was at least five times higher than that given by Jewell and O'Brien (45 mg kg body weight ${ }^{-1}$ day $\left.^{-1}\right)(8)$. It is of note that the induction of EROD, MROD and PROD observed by Jewell and O'Brien (8) was similar to that caused by the less pure annatto extract (28\% bixin) used in our study. Since the origin of bixin added to the diet in the Jewell and O'Brien's study was a commercial annatto extract (Annatto R35) containing only $42 \mathrm{~g}$ of bixin per $\mathrm{kg}$ of powder (4.2\% of bixin), enzyme induction could have been due to impurities or constituents of the extract other than bixin. Inducers of CYP1A and 2B have been found in cruciferous vegetables (broccoli, cabbage, Brussels sprouts) and garlic (Allium species), and in the essential oils of a large variety of plants 


\section{$(12,19,20)$.}

The rather weak effect of bixin on rat liver monooxygenases belonging to the CYP1A subfamily, on the other hand, indicated that this carotenoid, like $\beta$-carotene, lycopene and lutein, does not share the potent CYP1A1/2-inducing properties of apoor oxocarotenoids such as B-Apo-8'-carotenal, canthaxanthin and astaxanthin $(6,7)$. The mechanism underlying CYP1A induction by carotenoids is still unclear. Experiments on mice have demonstrated that canthaxanthin, like polycyclic aromatic hydrocarbons and 2,3,7,8 tetrachlorodibenzodioxin (TCDD), induces CYP1A1 and CYP1A2 through an Ah-receptor pathway (9). In mice, B-Apo-8'carotenal seems to induce specifically CYP1A2 (9). Canthaxantin and B-Apo-8'carotenal, however, did not compete with TCDD for the TCDD-binding site of the cytosolic Ah-receptor of mice (9).

As shown in Figure 1, there are no evident structural features separating the carotenoids which are potent inducers of CYP1A1/2 from those which do not act as inducers of these microsomal enzymes. Owing to this apparent lack of a structure-activity relationship, Gradelet et al. (9) advanced the hypothesis that common or similar me- tabolites of the three carotenoids (B-Apo-8'carotenal, canthaxanthin and astaxanthin) and not the parent compounds themselves are the ultimate inducing molecules. Nevertheless, little is known about the transformation of carotenoids in mammals, and it is still unclear which metabolites could be involved in the induction of liver microsomal enzymes.

Results from the present study showed that an annatto food coloring ( $28 \%$ bixin), given at oral doses as high as $250 \mathrm{mg} \mathrm{kg}^{-1}$ day $^{-1}$ for 5 consecutive days, induced CYP1A and $2 \mathrm{~B}$ subfamilies in the rat liver. Since a weaker induction was noted when rats received a similar treatment with bixin (95\% pure), it seems fair to conclude that constituents of the annatto extract other than bixin played an important role in the induction of CYP1A and 2B.

\section{Acknowledgments}

The authors are indebted to Baculerê Agroindustrial Ltda., Helianthus S.A. and the Center for Natural Colors (NCN, Brazil) for supplying annatto extracts, bixin and some reagents used in this study.

\section{References}

1. Camargo MTLA (1985). Medicina Popular: Aspectos Metodológicos para Pesquisa, Garrafada, Objeto de Pesquisa, Componentes Medicinais de Origem Vegetal, Animal e Mineral. ALMED Editora e Livraria Ltda., São Paulo, SP, Brazil.

2. Di Stasi LC, Santos EMG, Dos-Santos CM \& Hiruma CA (1989). Plantas Medicinais da Amazônia. Editora UNESP, São Paulo, SP, Brazil.

3. JECFA (1982). Evaluation of certain food additives and contaminants. Twenty-sixth Report of the Joint FAONHO Expert Committee on Food Additives. Technical Report Series, No. 683.

4. Hallagan JB, Allen DC \& Borzelleca JF (1995). The safety and regulatory status of food, drug and cosmetic colour additives exempt from certification. Food and Chemical Toxicology, 33: 515-528.

5. Astorg P, Gradelet S, Leclerc J, Canivenc MC \& Siess MH (1994). Effects of beta-carotene and canthaxanthin on liver xenobiotic-metabolizing enzymes in the rat. Food and Chemical Toxicology, 32: 735-742.

6. Gradelet S, Astorg P, Leclerc J, Chevalier J, Vernevaut MF \& Siess
$\mathrm{MH}$ (1996). Effects of canthaxanthin, astaxanthin, lycopene and lutein on liver xenobiotic-metabolizing enzymes in the rat. Xenobiotica, 26: 49-63.

7. Gradelet S, Leclerc J, Siess MH \& Astorg P (1996). Beta-Apo-8'carotenal, but not beta-carotene, is a strong inducer of liver cytochromes P4501A1 and 1A2 in the rat. Xenobiotica, 26: 909-919.

8. Jewell C \& O'Brien NM (1999). Effect of dietary supplementation with carotenoids on xenobiotic metabolizing enzymes in the liver, lung, kidney and small intestine of the rat. British Journal of Nutrition, 81: 235-242.

9. Gradelet S, Astorg P, Pineau T, Canivenc M-C, Siess M-H, Leclerc J \& Lesca P (1997). Ah receptor-dependent CYP1A induction by two carotenoids, canthaxanthin and B-Apo-8'-carotenal, with no affinity for the TCDD binding site. Biochemical Pharmacology, 54: 307-315.

10. Bradford MM (1976). A rapid and sensitive method for the quantitation of microgram quantities of protein utilizing the principle of protein dye binding. Analytical Biochemistry, 72: 248-254.

11. Burke MD, Thompson S, Elcombe CR, Halpert J, Haaparanta T \& 
Mayer RT (1985). Ethoxy-, penthoxy- and benzyloxyphenoxazones and homologues: a series of substrates to distinguish between different induced-cytochromes P-450. Biochemical Pharmacology, 34: 3337-3345.

12. De-Oliveira ACAX, Ribeiro-Pinto LF, Otto SS, Gonçalves A \& Paumgartten FJR (1997). Induction of liver monooxygenases by ßmyrcene. Toxicology, 124: 135-140.

13. Greenlee WF \& Poland A (1978). An improved assay of 7ethoxycoumarin O-deethylase activity: induction of hepatic enzyme activity in C57BL/6J and DBA/2J mice by phenobarbital, 3-methylcholanthrene and 2,3,7,8-tetrachlorodibenzo-p-dioxin. Journal of Pharmacology and Experimental Therapeutics, 205: 596-605.

14. Gibson GG \& Skett P (1994). Introduction to Drug Metabolism. 2nd edn. Blackie Academic \& Professional/Chapman \& Hall, London, England.

15. Burke MD, Thompsom S, Weaver RJ, Wolf CR \& Mayer RT (1994). Cytochrome P450 specificities of alkoxyresorufin-O-dealkylation in human and rat liver. Biochemical Pharmacology, 48: 923-936.

16. Funae $Y$ \& Imaoka S (1993). Cytochrome P450 in rodents. In:
Schenkman JB \& Greim H (Editors), Handbook of Experimental Pharmacology. 105, Cytochrome P450. Springer-Verlag, Heidelberg, Germany.

17. Klinger W, Lupp A, Karge E, Baumbach H, Eichhorn F, Feix A, Fulner F, Gernhardy S, Knels L, Kost B, Mertens G, Werner F, Oettel M, Romer W, Schwarz S, Elger W \& Schneider B (2002). Estradiol, testosterone, dehydroepiandrosterone and androstenedione: novel derivatives and enantiomers. Interactions with rat liver microsomal cytochrome P450 and antioxidant/radical scavenger activities in vitro. Toxicology Letters, 128: 129-144.

18. Hashemi E, Till C \& loannides C (2000). Stability of cytochrome P450 proteins in cultured precision-cut rat liver slices. Toxicology, 149: 51 61.

19. Hiroi T, Myiazaki $Y$, Kobayashi $Y$, Imaoka S \& Funae $Y$ (1995). Induction of hepatic P450s in rat by essential wood and leaf oils. Xenobiotica, 25: 457-467.

20. Okey AB, Riddick DS \& Harper PA (1994). The Ah receptor: mediator of the toxicity of 2,3,7,8-tetrachlorodibenzo-p-dioxin (TCDD) and related compounds. Toxicology Letters, 70: 1-22. 